\title{
The combined effect of dichloroacetate and 3-bromopyruvate on glucose metabolism in colorectal cancer cell line, HT-29; the mitochondrial pathway apoptosis
}

Hojatolla Nikravesh ${ }^{1,2}$, Mohammad Javad Khodayar ${ }^{2,3}$, Babak Behmanesh ${ }^{4}$, Masoud Mahdavinia ${ }^{2,3^{*}}$, Ali Teimoori ${ }^{5}$, Soheila Alboghobeish ${ }^{6}$ and Leila Zeidooni ${ }^{2}$

\begin{abstract}
Background: 5-Fluorouracil (5-FU) is regarded as the first line treatment for colorectal cancer; however, its effectiveness is limited by drug resistance. The ultimate goal of cancer therapy is induction of cancer cell death to achieve an effective outcome with minimal side effects. The present work aimed to assess the anti-cancer activities of mitocans which can be considered as an effective anticancer drug due to high specificity in targeting cancer cells.

Methods: MTT (3-4,5-dimethylthiazol-2-yl-2,5-diphenyltetrazolium bromide) assay was performed to determine the effects of our mitocans on cell viability and cell death. Apoptosis and necrosis, caspase 3 activity, mitochondrial membrane potential and ROS production in HT29 cell lines were analyzed by ApopNexin ${ }^{\text {TM }}$ FITC/PI Kit, Caspase- 3 Assay Kit, MitoTracker Green and DCFH-DA, respectively. Moreover, quantitative real-time polymerase chain reaction (qRT-PCR) was performed to detect the expression level of pro-apoptotic (Bax) and anti-apoptotic (BCl-2) genes in HT29 cell lines.

Results: Treatment with mitocans (3Br-P + DCA) inhibited the growth of HT29. Moreover, 3Br-P + DCA significantly induced apoptosis and necrosis, activation of caspase 3 activity, depolarize the mitochondrial membrane potential, and ROS production. At a molecular level, 3Br-P + DCA treatment remarkably down-regulated the expression of Bcl2, while up-regulated the expression of Bax.
\end{abstract}

Conclusion: Mitocans, in particular the combined drug, 3Br-P + DCA, could be regarded and more evaluated as a safe and effective compound for CRC treatment. Targeting hexokinase and pyruvate dehydrogenase kinase enzymes may be an option to overcome 5-FU -mediated chemo-resistant in colorectal cancer.

Keywords: Apoptosis, 3-Bromopyruvate, Dichloroacetate, Colorectal cancer cells, 5-fluorouracil

\footnotetext{
* Correspondence: mahdavinia-m@ajums.ac.ir

2Department of Toxicology, Faculty of Pharmacy, School of Pharmacy, Ahvaz Jundishapur University of Medical Sciences, Ahvaz, Iran

${ }^{3}$ Toxicology Research Center,Medical Basic Sciences Research Institute, Ahvaz Jundishapur University of Medical Sciences, Ahvaz, Iran

Full list of author information is available at the end of the article
}

(c) The Author(s). 2021 Open Access This article is licensed under a Creative Commons Attribution 4.0 International License, which permits use, sharing, adaptation, distribution and reproduction in any medium or format, as long as you give appropriate credit to the original author(s) and the source, provide a link to the Creative Commons licence, and indicate if changes were made. The images or other third party material in this article are included in the article's Creative Commons. licence, unless indicated otherwise in a credit line to the material. If material is not included in the article's Creative Commons licence and your intended use is not permitted by statutory regulation or exceeds the permitted use, you will need to obtain permission directly from the copyright holder. To view a copy of this licence, visit http://creativecommons.org/licenses/by/4.0/. The Creative Commons Public Domain Dedication waiver (http://creativecommons.org/publicdomain/zero/1.0/) applies to the data made available in this article, unless otherwise stated in a credit line to the data. 


\section{Background}

Cancer, a pathology characterized by unchecked division of cells, is one of the fatal diseases with an increasing number of cases all over the world [1]. Malignant neoplasms with the source of the intestine, rectum and anal canal, classified as colorectal cancer (CRC), are the third and second leading causes of death in males and females in the world, respectively [2]. Approximately, up to 1.8 million new cases of CRC were reported to occur yearly in the world, with an estimated 881,000 cases dying of this malignancy [3]. Despite substantial progresses in CRC screening measures and treatment, the prognosis of patients with this cancer remains poor, demanding novel therapeutic strategies to manage the disease [4]. In this respect, 5-Fluorouracil (5-FU) is a well-known anti-cancer drug commonly used to treat CRC; the agent interferes with DNA and RNA to disrupt the metabolism of the uracil, which lead to the breakdown of DNA and apoptosis of the cancer cells. Nonetheless, it is reported that the resistance to 5-FU during the course of CRC treatment plays a major role in treatment failure [5-7]. Therefore, the expansion and development of new and more effective drug combinations for CRC treatment is guaranteed. Studies show that some anti-cancer agents, known as mitocans, which exert their anti-tumor activities by modulating mitochondria, can be considered as an effective anti-cancer drug due to high specificity in targeting cancer cells [8]. Dichloroacetate (DCA) and 3bromopyruvate $(3 \mathrm{Br}-\mathrm{P})$ are two such anti-tumor agents, which belong to class 7 (hexokinase inhibitors) and class 1,7 (Krebs cycle inhibitors, hexokinase inhibitors) of mitocans, respectively [8]. DCA activates pyruvate dehydrogenase by inhibiting the pyruvate dehydrogenase kinase enzyme, which ultimately boosts the production of Acetyl-CoA, as a precursor of the Krebs cycle. The enhancement of the Krebs' cycle activity in turn increases the activity of the electron transfer chain; a function that increases the production of reactive oxygen species with mitochondrial origin, which lead to selective killing of cancer cells [9]. The another agent, $3 \mathrm{Br}-\mathrm{P}$, acts as a potent inhibitor of hexokinase; an enzyme that is overexpressed in cancer cells and is essential for the metabolism of cancer cells. The enzyme binds to voltage-dependent anion channel (VDAC, or porin) in the outer mitochondrial membrane, which results in resistance to chemotherapy by inhibiting glycolysis [10]. Recent studies reported that multi-target therapy acts more effective than single-target one [11]. Numerous studies have shown a synergistic action of DCA or 3Br-P with other compounds [12, 13]. However, the present work assessed the anticancer effects of $3 \mathrm{Br}-\mathrm{P}$ in combined with DCA in a colorectal cancer cell line, HT-29.

\section{Methods}

Human colorectal adenocarcinoma (HT-29) and human embryonic kidney 293 (HEK-293) cell lines were purchased from Iranian Biological Resource Center (Tehran, Iran). The anti-cancer agents, 5-FU and DCA/3Br-P, were supplied by Ebewe Pharma company and Sigma Aldrich (Saint Louis, MO), respectively. Dulbecco's modified eagle's medium (DMEM), fetal bovine serum (FBS), phosphate-buffered saline (PBS), and antibiotic (penicillin-streptomycin) were purchased from Invitrogen $\mathrm{Co}$, (Carlsbad, CA). Furthermore, MTT (3-(4,5-dimethylthiazol-2-yl)-2, 5-diphenyl tetrazolium bromide), 2,7dichlorofluorescein diacetate (DCFH-DA), Annexin V/ FITC apoptosis detection kit and MitoTracker Green supplied by Sigma Aldrich (Saint Louis, MO) were applied in this work. Moreover, Caspase 3 Assay kit, Bax, Bcl-2, and GAPDH primers were obtained from Qiagen (Hilden, Germany).

\section{Cell culture and treatment}

The cell lines, HT29 and HEK-293, were cultured in DMEM media with $10 \% \mathrm{FBS}$ at $37^{\circ} \mathrm{C}$, under a humidified atmosphere with $5 \% \mathrm{CO} 2$.

\section{Cell counting}

The trypan blue exclusion dye assay was applied to determine the number of living cells in a cell suspension. Shortly, $20 \mu \mathrm{l}$ of trypan blue dye $0.4 \%$ was added and mixed with equal parts of cell suspension in a micro tube. Subsequently, one side of a hemacytometer counter was filled with the cell suspension by placing the tip of the pipette at the notch, followed by counting the cells on the stage of a light microscope. The Calculation of cell percentage per milliliter was done via the following formula: cells $/ \mathrm{ml}=$ average count per square $\times$ dilution factor $\times 10^{4}$. Moreover, the experiments were performed at least for three times [14].

\section{Cytotoxicity assays}

Briefly, the HT-29 and HEK-293 cells were grown in 96well plate (5000cells/well) in $100 \mu \mathrm{l}$ medium and left overnight to adhere. Then, cells were treated with different concentrations of $3 \mathrm{Br}-\mathrm{P}(40,80,160$, and $320 \mu \mathrm{M})$; DCA $(40,80,160$ and $200 \mathrm{mM})$ and 5-FU (7.5, 15, 30, 60 and $120 \mu \mathrm{M})$ alone and combined with together, and incubate in media containing $10 \% \mathrm{FBS}$ at $37^{\circ} \mathrm{C}$ and $5-$ $6.5 \% \mathrm{CO} 2$ for $48 \mathrm{~h}$. After treatment, $10 \mu \mathrm{l}$ of the MTT (5 mg/ml in PBS) was added to each well and incubated for $3.5 \mathrm{~h}$ in $37^{\circ} \mathrm{C}$. Subsequently, the medium was removed and the formazan crystals were solubilized in $150 \mu \mathrm{l}$ of DMSO. Plates were covered with foil and 
Table 1 Sequences of the primers and PCR product sizes used in RT-PCR

\begin{tabular}{lll}
\hline Gene & Primer & Sequence \\
\hline GAPDH & Sense & 5'- CATCAATGGAAATCCCATCA - 3' \\
& Antisense & 5'- GACTCCACGACGTACTCAGC - 3' \\
Bax & Sense & 5'- GTCTTTTTCCGAGTGGCAGC - 3' \\
& Antisense & 5'- GTCCAATGTCCAGCCCATGA - 3' \\
Bcl-2 & Sense & 5'- ATGTGTGTGGAGAGCGTCAA - 3' \\
& Antisense & 5'- GGGCCGTACAGTTCCACAAA - 3'
\end{tabular}

GAPDH, glyceraldehyde 3-phosphate dehydrogenase; Bax, Bcl-2-associated X protein; Bcl-2, B cell lymphoma-2

shacked on an orbital shaker for $15 \mathrm{~min}$, and in the final step complete solubilization of the purple formazan crystals and reduced MTT were measured spectrophotometrically by microplate enzyme-linked immunosorbent assay (ELISA) reader at $570 \mathrm{~nm}$ according to the filters available for the ELISA reader. Viability inhibition was calculated as follows: cell viability $(\%)=\mathrm{Ab}$ (test) $/ \mathrm{Ab}($ control $) \times 100$ [15]. To calculate the Combination Index $(\mathrm{CI})$, cells were treated with a combination of $\mathrm{DCA}$ and $3 \mathrm{Br}-\mathrm{P}$ using the method of constant ratio drug combination proposed by Chou and Talalay [16].

\section{Measurement of apoptosis and necrosis}

This was measured according to ApopNexin ${ }^{\mathrm{Tm}}$ FITC/PI Kit instructions. In summary, $1.5 \times 10^{5}$ cells were seeded and treated with different concentrations of $3 \mathrm{Br}-\mathrm{P}, \mathrm{DCA}$ and 5-FU alone and combined together in HT-29 cells for $48 \mathrm{~h}$. After drug exposure, the cells were harvested, and then were washed with ice-cold PBS and stained with ApopNexin $^{\text {Ts }}$ FITC kit for $15 \mathrm{~min}$ at room temperature in the dark. Stained samples were analyzed by Galaxy flow cytometer (ser. No: 0105362) [17].

\section{Caspase 3 assay}

Caspase 3 activity was determined via using the specific caspase- 3 substrate, prepared by Caspase- 3 Assay Kit, Colorimetric Qiagen (Hilden, Germany). In short, after treating the cells with $3 \mathrm{Br}-\mathrm{P}, \mathrm{DCA}$ and 5-FU alone and/ or combined together, the caspase- 3 activity was measured by ELISA at $504 \mathrm{~nm}$, according to the protocol of the kit [18].

\section{Mitochondrial membrane potential $\left(\Delta \Psi_{\mathrm{m}}\right)$}

MitoTracker Green is a fluorescent color that selectively attaches covalently to mitochondrial proteins in the mitochondrial matrix by reacting with free thiol groups of cysteine roots. Briefly, in each well of 24-well plates, about $10^{5}$ cells were seeded and incubated overnight,

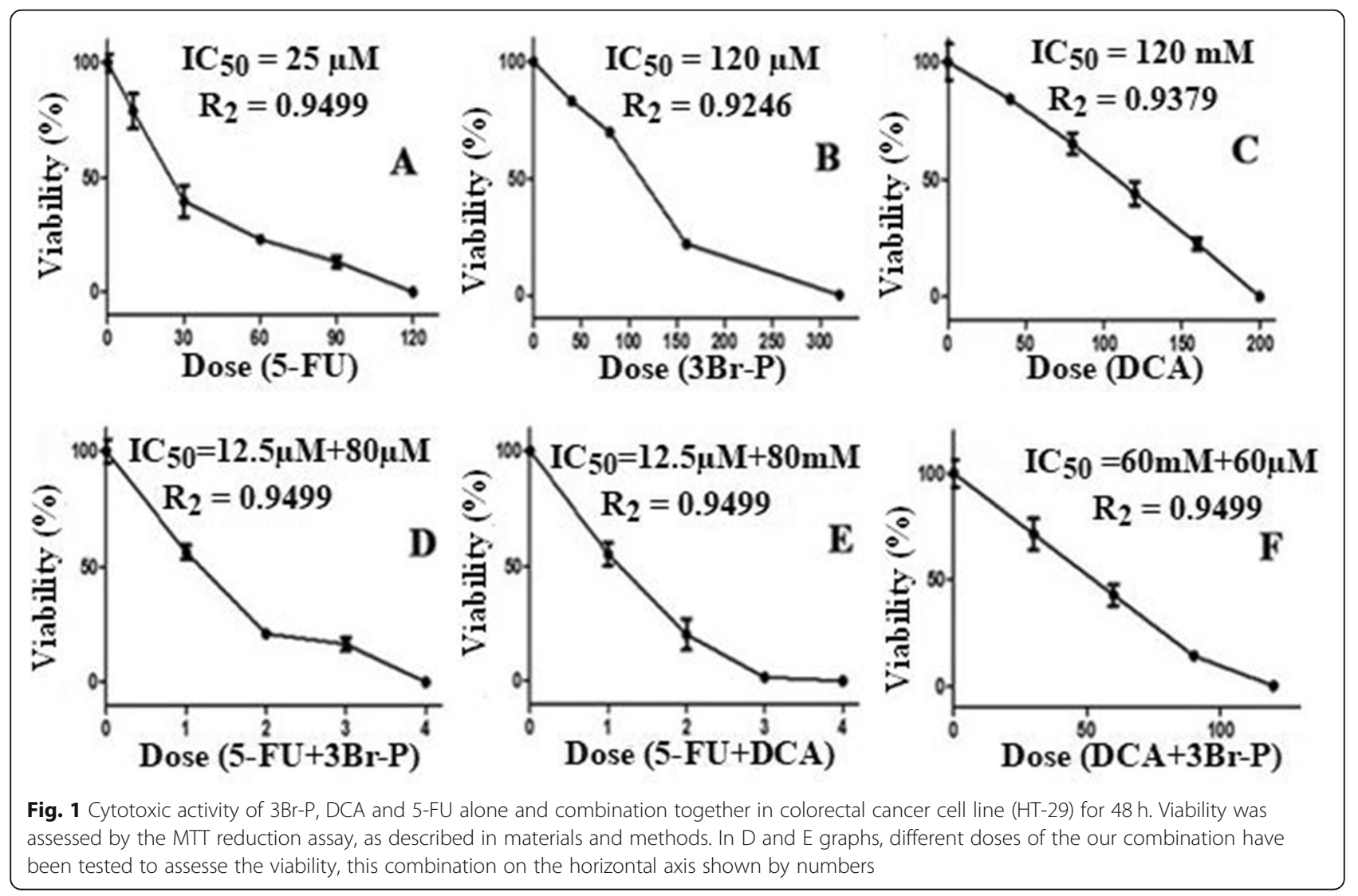


and subsequently treated with $3 \mathrm{Br}-\mathrm{P}, \mathrm{DCA}$ and 5-FU alone and/or combined together for $48 \mathrm{~h}$. Then, the cells were harvested and incubated with $10 \mu \mathrm{l}$ of MitoTracker Green for $30 \mathrm{~min}$ at $37^{\circ} \mathrm{C}$ in a $5 \% \mathrm{CO} 2$ incubator. After incubation, the samples were placed on ice and immediately were assessed by flow cytometry [19].

\section{Determination of ROS production}

To perform this, 24-well plates were seeded with $10^{5}$ cells in a complete culture medium and allowed to adhere overnight. In all wells (90\% confluence) treated with 3Br-P, DCA and 5-FU alone and/or combined together, cells were washed twice with PBS, followed by staining with $10 \mu \mathrm{M}$ DCFH-DA for $45 \mathrm{~min}$. Then, after 2, 4, 8, and $12 \mathrm{~h}$, the formation of fluorescent-oxidized DCF was measured by fluorimetry $(535 \mathrm{~nm}$ excitation and $635 \mathrm{~nm}$ emission) [20].

\section{$R T-P C R$ and $q P C R$ reaction}

Total RNA was isolated according to the manufacturer's instructions supplied by Rneasy Mini Kit (QIAgEN-cat. No. 74106.). Afterwards, cDNA was synthesized from $2 \mu \mathrm{g}$ of the total RNA using the Prime Script RT-PCR kit (Quanti Tect Rev. Transcription Kit), according to the manufacturer's instructions. Quantitative real-time PCR (qPCR) assays were performed with Roche LightCycler in 96-wells Gene Discs, using a final reaction volume of $20 \mu \mathrm{L}$ containing $0.4 \mu \mathrm{l}$ of each forward and reverse primers (with concentration of $10 \mu \mathrm{mol} / \mathrm{L}$ ) (Table 1), 2x SYBR Green master mix (as indicated in the results section) and $<1 \mathrm{ng} / \mu \mathrm{l}$ of cDNA samples. The following thermal profile was applied; the cycling conditions used were as follows: $95^{\circ} \mathrm{C}$ for $15 \mathrm{~min}$; 30 cycles of $95^{\circ} \mathrm{C}$ for $15 \mathrm{~s}, 66^{\circ} \mathrm{C}$ for 30 Sec. Melting curve analysis was performed by ramping the temperature from $60^{\circ} \mathrm{C}$ to $90^{\circ} \mathrm{C}$. All reactions were conducted in triplicate. The
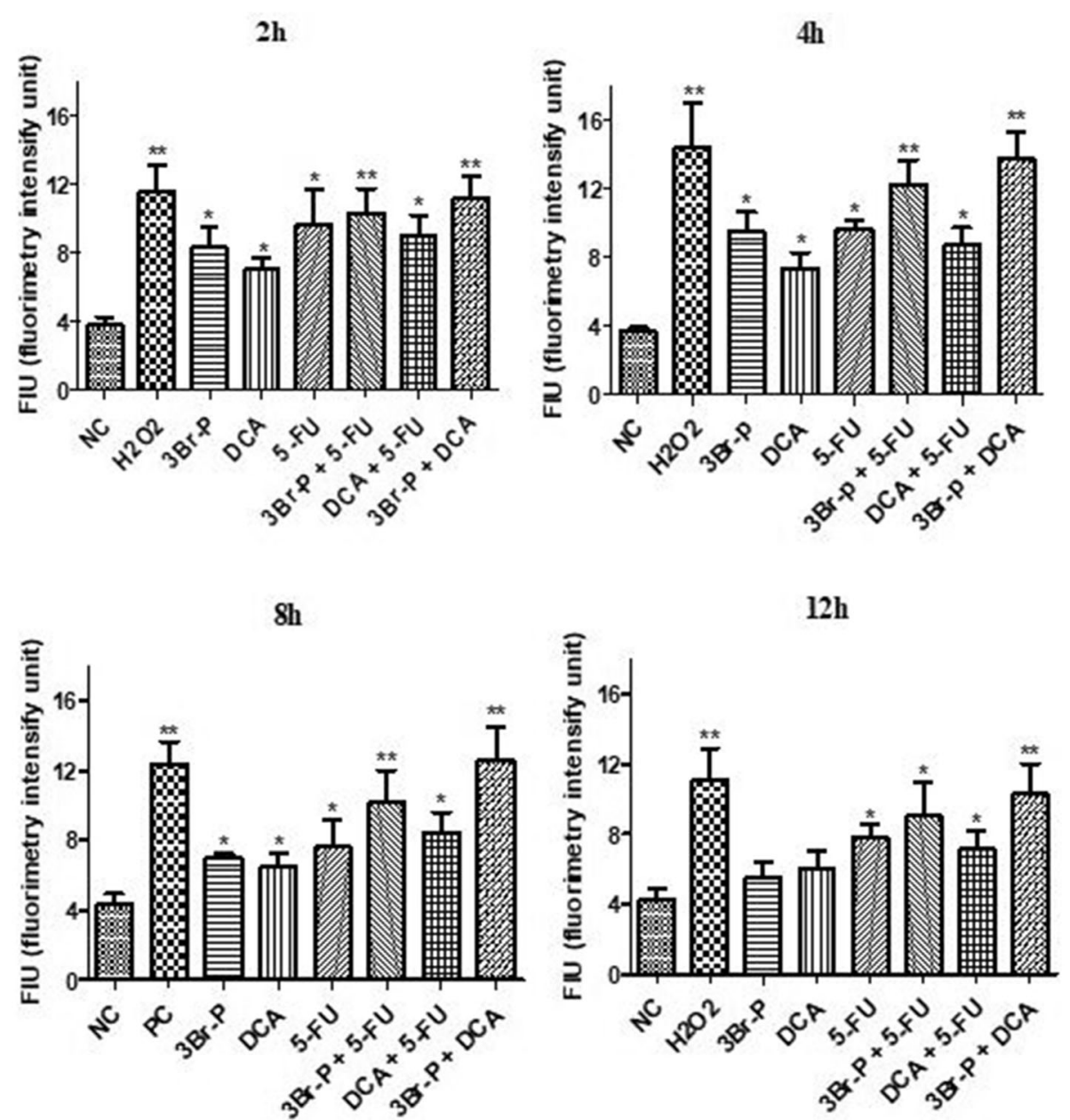

Fig. 2 Effect of 3Br-P, DCA, and 5-FU alone and/or combined together on ROS production in HT-29 cell line after $2 \mathrm{~h}, 4 \mathrm{~h}, 8 \mathrm{~h}$, and $12 \mathrm{~h}$. Data presented as Mean \pm SEM. *: $(p<0.05)$ designates significant difference with control, ${ }^{*}:(p<0.05)$ designates significant difference with control, 3Br-P, DCA, 5-FU alone and/or combined together 


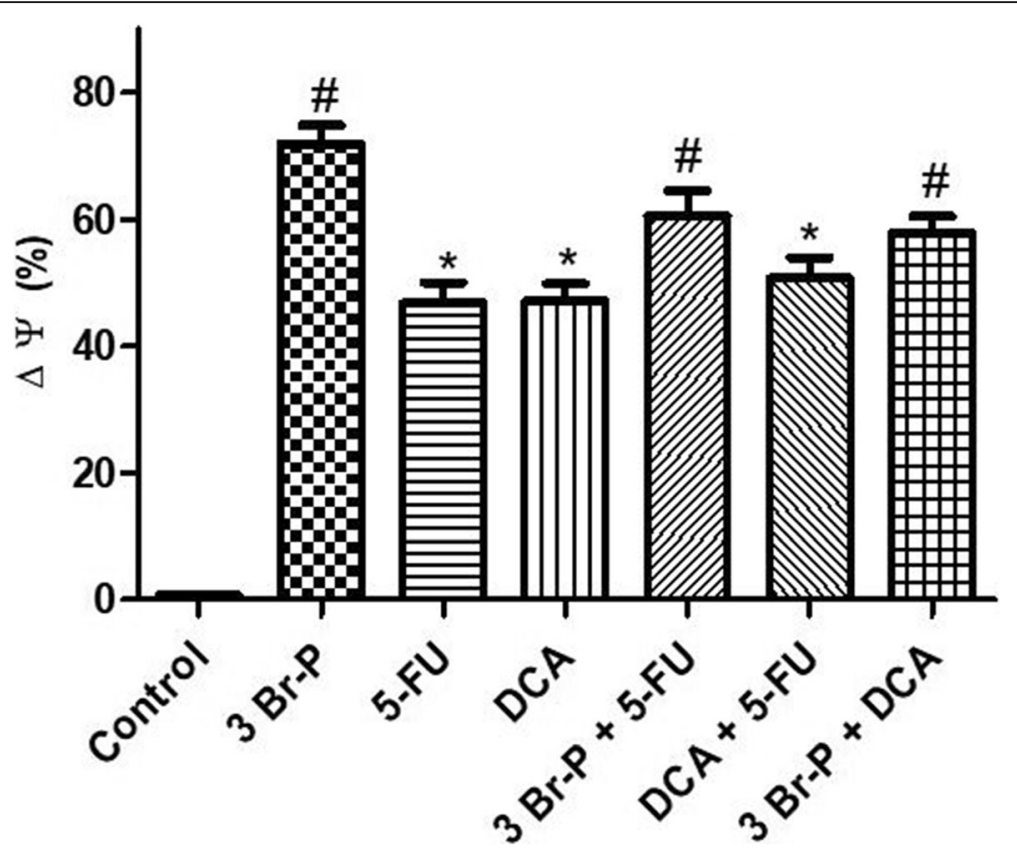

Fig. 3 Effect of 3Br-P, DCA, and 5-FU alone and/or combined together on loss of mitochondrial membrane potential $(\Delta \psi)$ in HT-29 cell line after $48 \mathrm{~h}$. Data presented as Mean \pm SEM. *: $(p<0.05)$ designates significant difference with control, ${ }^{\#}:(p<0.05)$ designates significant difference with control, 5-FU, DCA and DCA + 5-FU

fold change of gene expression was calculated using $2^{-\Delta \Delta \mathrm{Ct}}$ after normalizing to the expression level of GAPDH.

\section{Statistical analysis}

All experiments were performed at least through 3 trials. All quantitative data are expressed as mean $\pm \mathrm{SD}$. Oneway analysis of variance (ANOVA) followed by Tukey's multiple comparisons were executed for comparison of different parameters between the groups using a
GraphPad Prism 5 software (GraphPad Prism, San Diego, California, The U.S.A.).

\section{Results}

\section{In vitro cytotoxicity}

In the present study, cytotoxicity was assessed in the different cell lines by using MTT assay. The IC50 values for the HT-29 cell line obtained from the study are reported as follows: 5-FU;25 $\mu \mathrm{M}, 3 \mathrm{Br}-\mathrm{P} ; 120 \mu \mathrm{M}, \mathrm{DCA} ; 120$ $\mathrm{mM}, \quad 5-\mathrm{FU}+3 \mathrm{Br}-\mathrm{P} ; 12.5 \mu \mathrm{M}+80 \mu \mathrm{M}, \quad 5-\mathrm{FU}+\mathrm{DCA}$; $12.5 \mu \mathrm{M}+80 \mathrm{mM}, \quad 3 \mathrm{Br}-\mathrm{P}+\mathrm{DCA} ; \quad 60 \mu \mathrm{M}+60 \mathrm{mM}$.
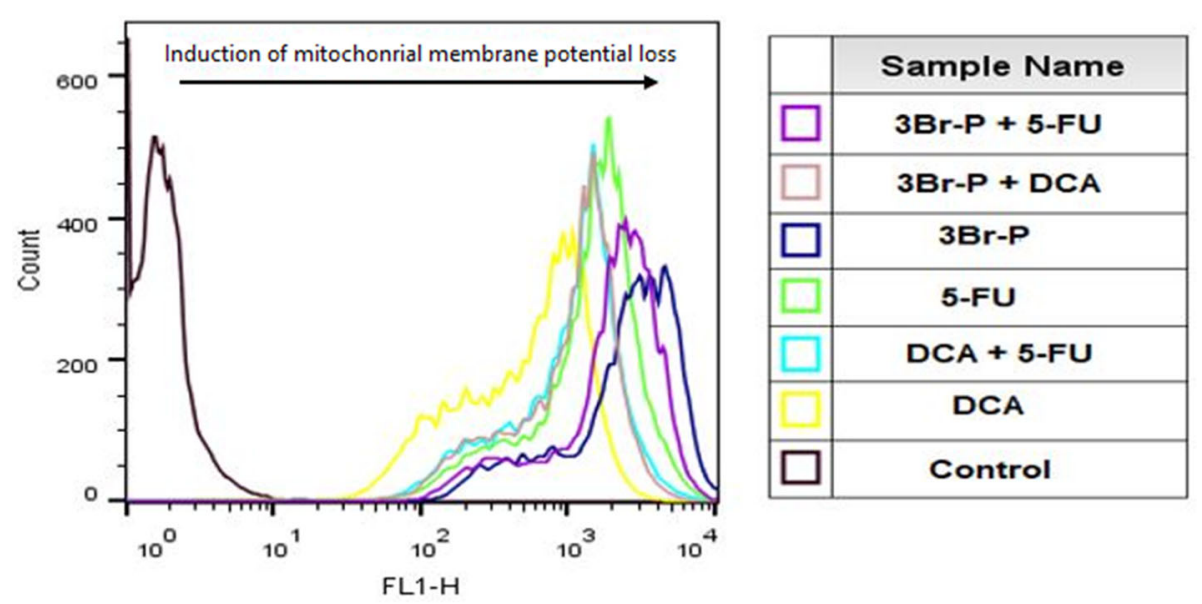

Fig. 4 Mitochondrial membrane potential was measured using fluorescent dye mito tracker green and flow cytometry in colorectal cancer cell line (HT-29) treated with 3Br-P, DCA and 5-FU alone and/or combined together. (FL1 $525 \mathrm{~nm}$ band pass filter green) 
Nonetheless, in the normal cell line, HEK-293, the above mentioned doses had no significant effects at $48 \mathrm{~h}$ after treatment (Fig. 1). The data with HEK-293 cells shown in additional results.

\section{In vitro ROS activity}

The ROS activity in the treated group was shown to be significantly higher than the untreated ones, at the times of 2, 4 and $8 \mathrm{~h}$ after treatment. Furthermore, among the mentioned times in the treated group, the ROS amount was found to be higher during $4 \mathrm{~h}$ after treatment. Moreover, the combinations of $5-\mathrm{FU}+3 \mathrm{Br}-\mathrm{P}$ and $3 \mathrm{Br}-$ $\mathrm{P}+\mathrm{DCA}$ in the treated HT-29 cells produced more ROS amount than the other compounds (Fig. 2).

\section{In vitro assessment of mitochondrial membrane potential} $\left(\Delta \Psi_{\mathrm{m}}\right)$

Based on our results, the compound 3Br-P significantly promoted $\Delta \Psi \mathrm{m}$ reduction in $\mathrm{HT}-29$ cells in comparison with the control and other treated groups. These results show that the combined agents, including 5-FU + 3Br-P, $5-\mathrm{FU}+\mathrm{DCA}$, and 3Br-P + DCA significantly increased
$\Delta \Psi \mathrm{m}$ lose in HT-29 cells in compared to the control (Fig. 3).

Mitotracker green dye accumulates in the mitochondrial matrix where it covalently reacts with free thiol groups of cysteine residues and produce green fluorescence (FL1 $525 \mathrm{~nm}$ band pass filter green). The intensity of this emitted fluorescent indicates mitochondrial membrane potential loss (Fig. 4). Changes in mitochondrial morphology and mitochondrial fragmentation measured via a fluorescence microscope, the intensity of this emitted fluorescent also indicates the mitochondrial degeneration (Fig. 5).

\section{Caspase 3 assay}

Treatment of the HT-29 cells with all the assessed compounds (5-FU, 3Br-P, DCA, 5-FU+ DCA, 5-FU + 3Br-P, and $3 \mathrm{Br}-\mathrm{P}+\mathrm{DCA})$ significantly increased the caspase 3 activity in compared to untreated cells $(p \leq 0.05)$ (Fig. 6).

\section{Quantification of the $\mathrm{Bax} / \mathrm{Bcl}-2$ ratio}

Treatment of the HT-29 cells with 5-FU, 3Br-P, DCA, 5$\mathrm{FU}+\mathrm{DCA}, 5-\mathrm{FU}+3 \mathrm{Br}-\mathrm{P}$, and $3 \mathrm{Br}-\mathrm{P}+\mathrm{DCA}$ significantly increased the $\mathrm{Bax} / \mathrm{Bcl}-2$ genes expression in compared

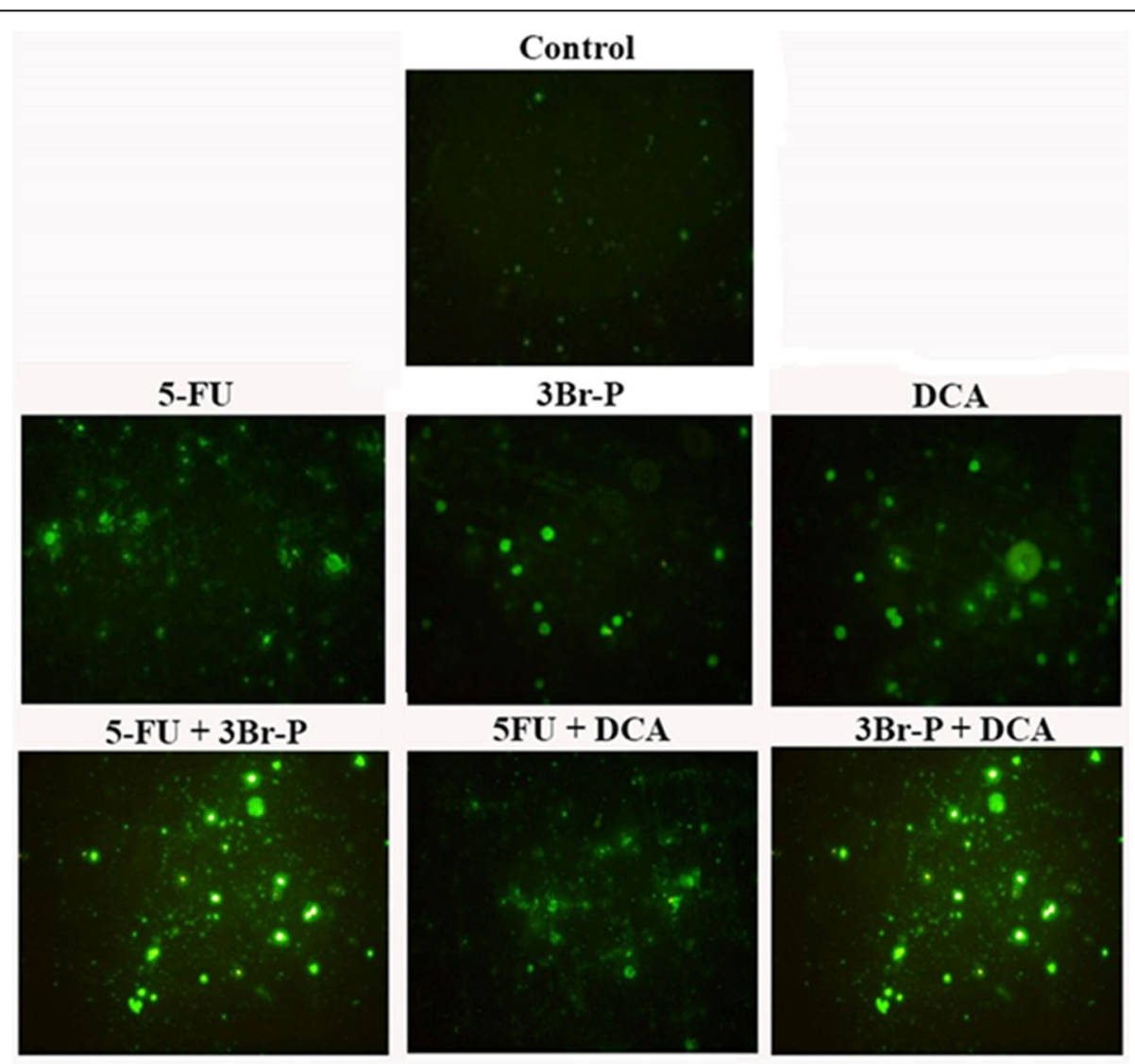

Fig. 5 Mitochondrial membrane potential changes in colorectal cancer cell line (HT-29) measured via a fluorescence microscope (20X) 48 h after exposure to 3Br-P, DCA, and 5-FU alone and/or combined together 


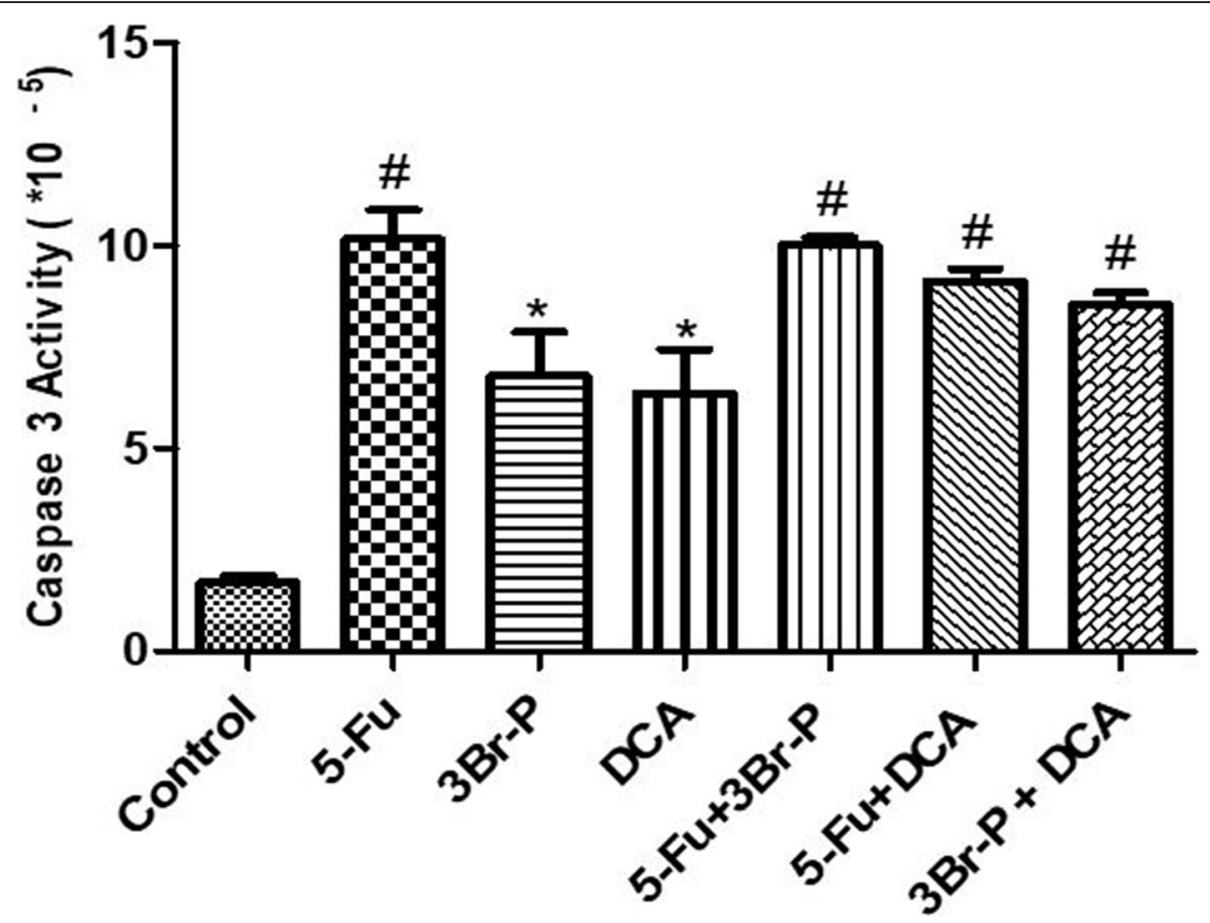

Fig. 6 Effect of 3Br-P, DCA, and 5-FU alone and/or combined together on caspase 3 activity in HT-29 cell line after 48 h. Data presented as Mean \pm SEM. *: $(p<0.05)$ designates significant difference with control. "*: $(p<0.05)$ designates significant difference with control, DCA and 3Br-P

\section{$B a x / B c / 2$ Expression}

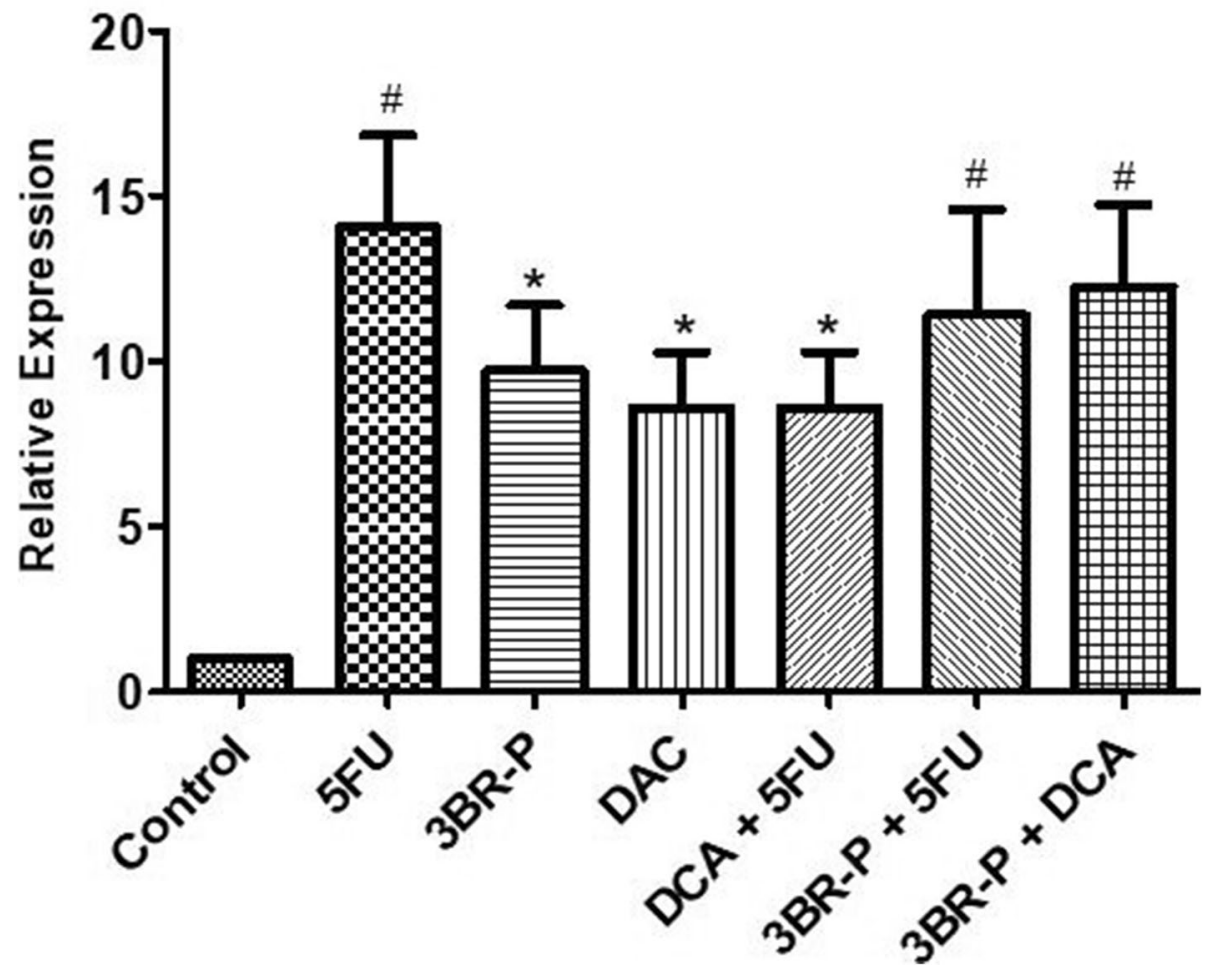

Fig. 7 Effect of 3Br-P, DCA, and 5-FU alone and/or combined together on gene expression, in HT-29 cell line after $48 \mathrm{~h}$. Data presented as Mean \pm SEM. *: $(p<0.05)$ designates different with control, ${ }^{\#}:(p<0.05)$ designates different with control, 3Br-P, DCA, 5-FU + DCA 
to the control ones $(p \leq 0.05)$. Interestingly, there was no a significant difference of the $\mathrm{Bax} / \mathrm{Bcl}-2$ gene expression between HT-29 cells treated with 5-FU alone and those treated by 3Br-P + DCA (Fig. 7).

\section{Induction of apoptosis and necrosis by flow cytometry}

Annexin-V FITC/PI staining confirmed that 5-FU, 3Br$\mathrm{P}, \mathrm{DCA}, 5-\mathrm{FU}+\mathrm{DCA}, 5-\mathrm{FU}+3 \mathrm{Br}-\mathrm{P}$, and 3Br-P + DCA could induce apoptosis in HT-29 cells. All the treated HT-29 cells had a significant higher necrotic pattern as compared to untreated cells $(\mathrm{p} \leq 0.05)$. It was found that the treatment with 5-FU significantly increases the percentage of apoptosis from $0.465 \%$ in the control cells to $32.35 \%$ in the treating cells. Moreover, the 5-FU + DCA, $5-\mathrm{FU}+3 \mathrm{Br}-\mathrm{P}$, and $3 \mathrm{Br}-\mathrm{P}+\mathrm{DCA}$ groups had a significantly increased apoptosis in compared to the control, $3 \mathrm{Br}-\mathrm{P}$ and DCA groups (Fig. 8).

\section{Discussion}

Globally, CRC is the second and third leading causes of death in women and men, respectively [21]. The aim of cancer therapy is to inhibit proliferation (cytostatic effects) and to induce cell death (cytotoxic effects) of cancer cells [22], to achieve an effective outcome with minimal side effects [23]. In most cancers, the first therapeutic strategy used to treat is surgical removal. Obviously, surgery for some types of cancers is relatively simple and for other types is impractical [23]. Therefore, chemotherapy and radiotherapy are used to control or eradicate metastatic cells. Traditional chemotherapy is the use of drugs to target the cell cycle, DNA, RNA, and proteins in cancer cells. 5-FU is the first traditional chemotherapy and the first choice for CRC therapy, whose effectiveness is limited by drug resistance [24]. Mitochondria have emerged as an attractive target for

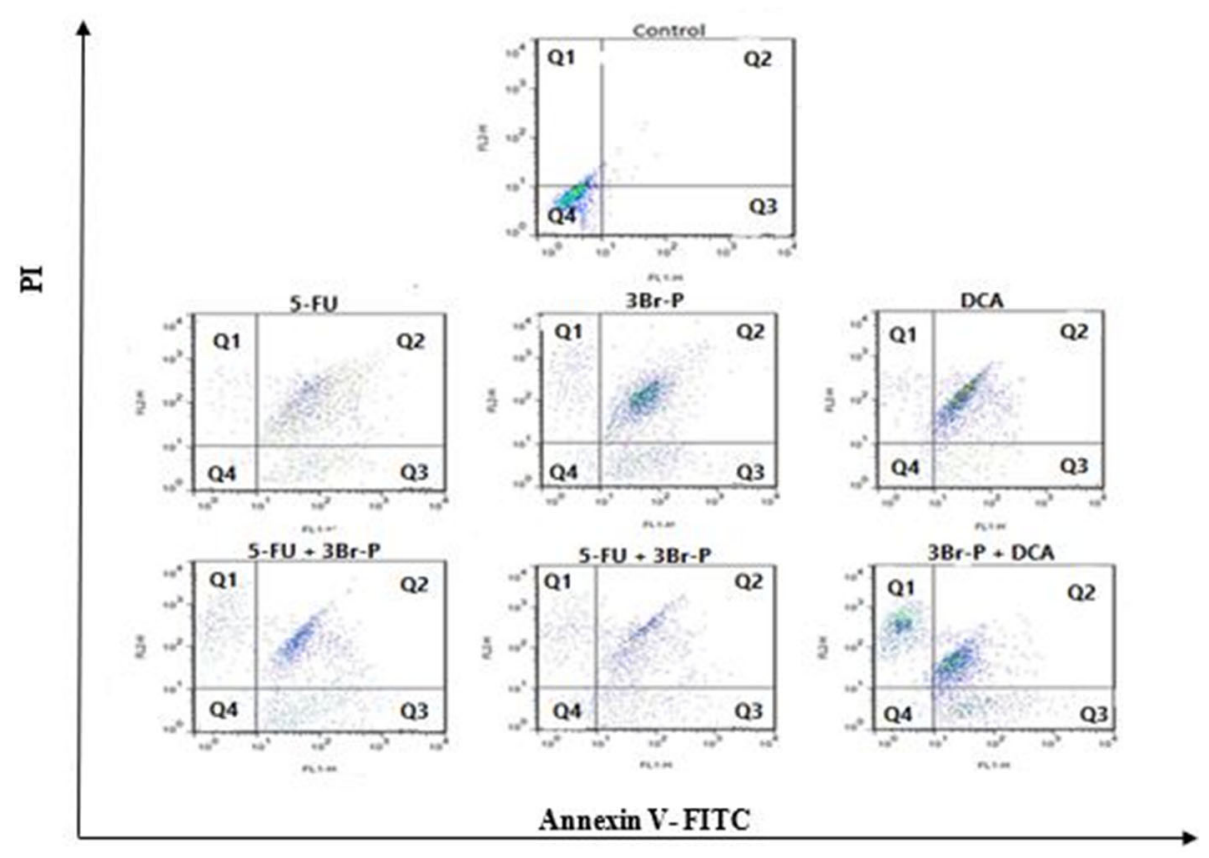

\begin{tabular}{|c|c|c|c|c|}
\hline Treatment & Q1 (\%) & Q2 (\%) & Q3 (\%) & Q4 (\%) \\
\hline Control & 6.16 & 0.930 & 0.465 & 92.4 \\
\hline 5-FU & $3.67^{\star}$ & 62.14 & $32.35^{\circ}$ & 1.84 \\
\hline 3Br-P & $13.75^{*}$ & 57.7 & $18.68^{*}$ & 9.87 \\
\hline DCA & $7.01^{*}$ & 81 & $10.4^{*}$ & 1.62 \\
\hline 3Br-P+5-FU & $16.09^{*}$ & 50.69 & $6.08^{*}$ & 27.14 \\
\hline DCA+5-FU & $17.85^{*}$ & 44.82 & $24.36^{*}$ & 2.61 \\
\hline 3Br-P+DCA & $27.37^{\circ}$ & 49.58 & $21.2^{*}$ & 1.85 \\
\hline
\end{tabular}

Fig. 8 Fig. 8: Flow cytometry assessment of apoptosis and necrosis in HT-29 cell line after 48 h treatment with 3Br-P, DCA, and 5-FU alone and/or combined together. Data presented as Mean \pm SEM. *: $(p<0.05)$ designates significant difference with control, \#: $(p<0.05)$ designates significant difference with control, $3 \mathrm{Br}-\mathrm{P}$ and DCA, \$: $(p<0.05)$ designates significant difference with control, 3Br-P, DCA, and/or combined together. Treated cells were stained with Annexin V-FITC/ PI assay. Four quadrants (Q) representing normal cells (Q4), early apoptosis cells (Q3), late apoptotic/ necrotic cells (Q2) and necrotic cells (Q1) 
anticancer drugs, so that the compounds such as mitocans that target mitochondria with anti-cancer activity has become a focus of recent research due to their great clinical potential $[24,25]$. In our study, we have described the cytotoxic effect of the mitochondria-targeted drugs, 3Br-P + DCA, in HT-29 cell line and assessed the mechanism of its action. Recent studies have shown that therapies having multiple targets result in greater benefits than single-targeted therapies [26]. There are several studies suggesting a synergistic action of $3 \mathrm{Br}-\mathrm{P}$ or DCA with other compounds. For instance, the selective inhibitor of glycolytic enzymes, $3 \mathrm{Br}-\mathrm{P}$, when combined with sodium citrate (SCT), resulted in reduced ATP level, induced mitochondrial-mediated apoptosis, and suppressed tumor growth in gastric cancer cells [27]. In the same way, when cisplatin or oxaliplatin combined with $3 \mathrm{Br}-\mathrm{P}$, amazingly boosted the antiproliferative effects of the platinum drugs in HCT116 cells [28]. Moreover, antitumor effects of tamoxifen, the first-line adjuvant endocrine therapy for estrogen receptor-positive breast cancer, were markedly improved when used with $3 \mathrm{Br}-\mathrm{P}$, as a sensitizer to target glycolysis [29]. On the other hand, in colorectal cancer cells parallel results were obtained using traditional chemotherapy drugs with DCA. Ayyanathan et al. demonstrated that the combination of DCA and sulindac augments the selective killing of
A549 and SCC25 cancer cells via ROS production, mitochondrial dysfunction, and apoptosis [30]. Similarly, Florio et al., reported that the combination of three metabolic drugs, DCA, GW6471, and metformin resulted in a remarkable enhanced ROS production, modulated cell cycle progression, and promoted apoptosis in PGL cells [31]. These findings are in line with the results reported in our study. In the present study, we found that DCA and 3Br-P together or in combined with 5-FU significantly reduced cell viability and proliferation of HT-29 cell lines (Fig. 8). Apoptosis plays an important role in treatment of cancer, as it is a popular target of many treatment strategies [32]. Accordingly, we showed that the combined drug therapy, DCA $+3 \mathrm{Br}-\mathrm{P}$, promotes apoptosis more effectively than the single therapies in HT-29 cell lines (Fig. 8); a mechanism that may be induced by modulating pathways such as ROS-dependent apoptosis in HT-29 cell lines. In the mitochondrial (caspase-dependent intrinsic) pathway that induces apoptosis, caspases, in particular caspase-3, are crucial mediators for the apoptotic machinery in many cell types [33]. This pathway is controlled by B-cell lymphoma-2 (BCL2) family proteins, composed of members that either promote or inhibit apoptosis. A major checkpoint in cellular fate is a balance formed between pro-apoptotic (Bax) and anti-apoptotic (Bcl-2) members

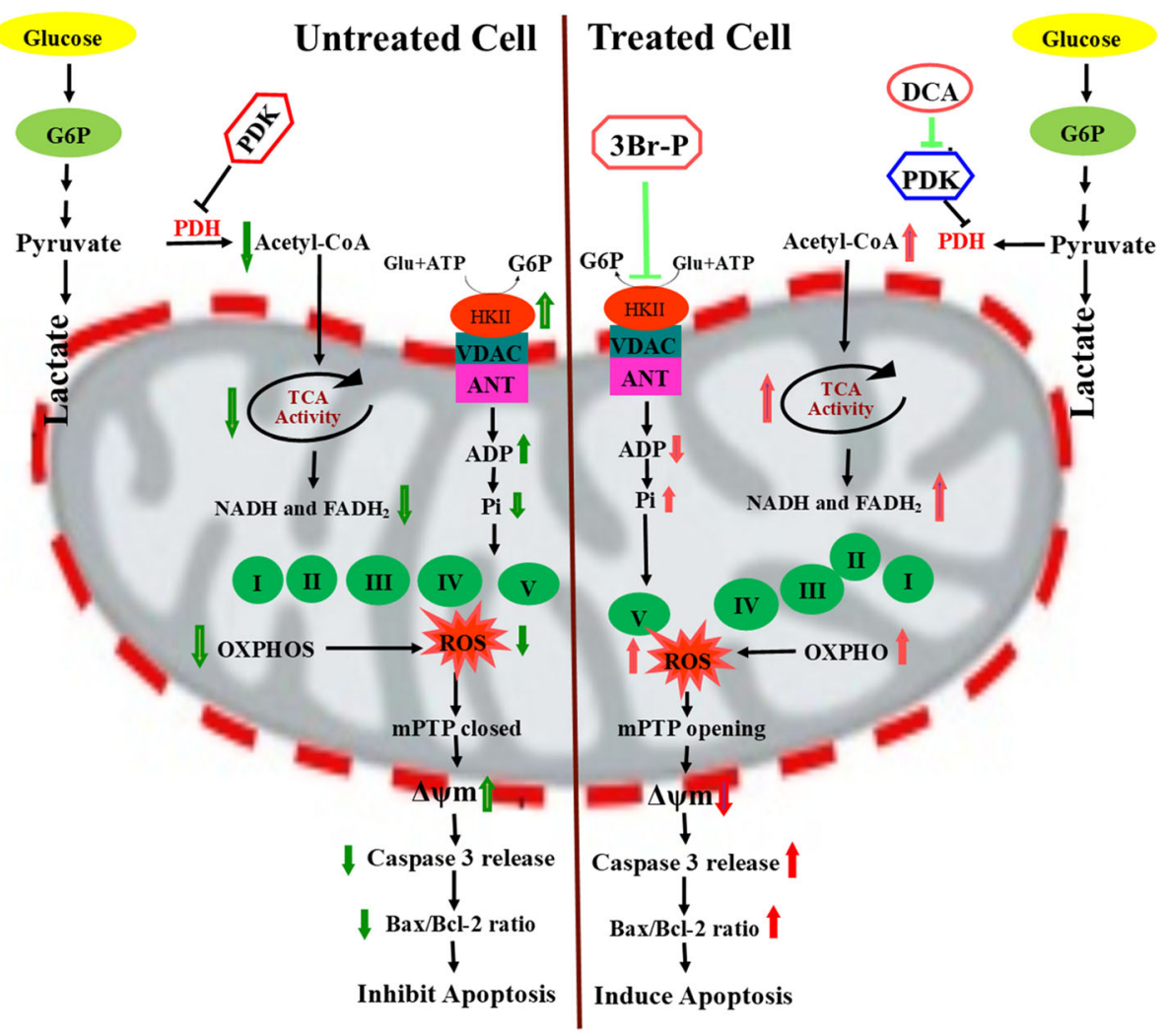

Fig. 9 Represented regarding apoptotic effects of 3Br-P combined with DCA in colorectal cancer cell line HT-29 
[34]. Increased $\mathrm{Bax} / \mathrm{Bcl}-2$ ratio up-regulates caspase-3, which leads to apoptosis of tumor cells [35]. In the current study, we evaluated caspase 3 release, Bax/Bcl-2 ratio expression and mitochondrial membrane potential $(\Delta \Psi \mathrm{m})$. The results demonstrated that the three mentioned parameters increased by the combined drug therapy $(\mathrm{DCA}+3 \mathrm{Br}-\mathrm{P})$ in comparison to single drug therapy. As a result, more studies are needed to investigate the mechanisms underlying the anticancer effect of combined $3 \mathrm{Br}-\mathrm{P}+\mathrm{DCA}$ and a combination of other mitocans treatment on CRC cells (Fig. 9).

\section{Conclusion}

We have indicated that a combination of $3 \mathrm{Br}-\mathrm{P}+\mathrm{DCA}$ exerts an antitumor effect in vitro by activation of mitochondria-dependent apoptosis. The first goal of target therapy is to fight cancer cells with more precision and fewer side effects potentially. Targeted cancer therapies were designed to target a specific molecule that is critical for the growth and expansion of cancer cell, hence, blocking these molecules can kill cancer cells without any harm to normal cells. According to the mitocans features, we can consider them as apoptosis inducers. However, the results of the combination of $3 \mathrm{Br}$ $\mathrm{P}+\mathrm{DCA}$ in this study have no significant difference with the 5-FU alone; however, we should never ignore the primary goal of this study to show that combination therapy has lower side effects and resistance to treatment.

\section{Abbreviations}

CRC: colorectal cancer; 5-FU: 5-Fluorouracil; MTT: 3-4,5-dimethylthiazol-2-yl2,5-diphenyltetrazolium bromide; qRT-PCR: quantitative real-time polymerase chain reaction; DCA: Dichloroacetate; 3Br-P: 3-bromopyruvate; VDAC: voltagedependent anion channel; HT-29: Human colorectal adenocarcinoma; HEK293: human embryonic kidney 293; SCT: sodium citrate

\section{Supplementary Information}

The online version contains supplementary material available at https://doi. org/10.1186/s12885-021-08564-3.

\section{Additional file 1.}

\section{Acknowledgements}

We are grateful to all persons contributing for promoting this investigation.

\section{Authors' contributions}

M.M. and M.J.K. study concept and design, critical revision of the manuscript for important intellectual content; B.B. acquisition of data, analysis, and interpretation of data; S.A. and L.Z. statistical analysis; A.T. and H.N. administrative, technical, and material supports, drafting of the manuscript; The author(s) read and approved the final manuscript.

\section{Funding}

This study was financially supported by Cellular and Molecular Research Center, Ahvaz Jundishapur University of Medical Sciences, Ahvaz, Iran (Grant number CMRC-9517).

\section{Availability of data and materials}

The datasets used and/or analyzed during the current study are available from the corresponding author on reasonable request.

\section{Declarations}

Ethics approval and consent to participate

Not applicable.

\section{Consent for publication}

Not applicable.

\section{Competing interests}

The Authors declare that they have no competing interests.

\section{Author details}

${ }^{1}$ Cellular and Molecular Research Center, Medical Basic Sciences Research Institute, Ahvaz Jundishapur University of Medical Sciences, Ahvaz, Iran.

${ }^{2}$ Department of Toxicology, Faculty of Pharmacy, School of Pharmacy, Ahvaz Jundishapur University of Medical Sciences, Ahvaz, Iran. ${ }^{3}$ Toxicology Research Center,Medical Basic Sciences Research Institute, Ahvaz Jundishapur University of Medical Sciences, Ahvaz, Iran. ${ }^{4}$ Student Research Committee, Ahvaz Jundishapur University of Medical Sciences, Ahvaz, Iran. ${ }^{5}$ Department of Virology, Faculty of Medicine, Hamadan University of Medical Sciences, Hamadan, Iran. ${ }^{6}$ Department of Pharmacology, Faculty of Pharmacy, Ahvaz Jundishapur University of Medical Sciences, Ahvaz, Iran.

Received: 12 April 2021 Accepted: 7 July 2021

Published online: 07 August 2021

\section{References}

1. Yu MK, Park J, Jon S. Targeting strategies for multifunctional nanoparticles in cancer imaging and therapy. Theranostics. 2012;2(1):3-44. https://doi.org/10. 7150/thno.3463

2. Rasouli MA, Moradi G, Roshani D, Nikkhoo B, Ghaderi E, Ghaytasi B. Prognostic factors and survival of colorectal cancer in Kurdistan province, Iran: A population-based study (2009-2014). Medicine (Baltimore). 2017:96(6).

3. Bray F, Ferlay J, Soerjomataram I, Siegel RL, Torre LA, Jemal A. Global cancer statistics 2018: GLOBOCAN estimates of incidence and mortality worldwide for 36 cancers in 185 countries. CA Cancer J Clin. 2018;68(6):394-424. https://doi.org/10.3322/caac.21492.

4. Van Cutsem E, Cervantes A, Adam R, Sobrero A, Van Krieken JH, Aderka D, et al. ESMO consensus guidelines for the management of patients with metastatic colorectal cancer. Ann Oncol. 2016;27(8):1386-422. https://doi. org/10.1093/annonc/mdw235.

5. Nazim UMD, Rasheduzzaman M, Lee Y-J, Seol D-W, Park S-Y. Enhancement of TRAlL-induced apoptosis by 5 -fluorouracil requires activating Bax and p53 pathways in TRAll-resistant lung cancers. Oncotarget. 2017;8(11):18095105. https://doi.org/10.18632/oncotarget.14994.

6. O'Connell MJ, Martenson JA, Wieand HS, Krook JE, Macdonald JS, Haller DG, et al. Improving adjuvant therapy for rectal cancer by combining protractedinfusion fluorouracil with radiation therapy after curative surgery. N Engl J Med. 1994;331 (8):502-7. https://doi.org/10.1056/NEJM199408253310803.

7. André T, Boni C, Mounedji-Boudiaf L, Navarro M, Tabernero J, Hickish T, et al. Oxaliplatin, fluorouracil, and leucovorin as adjuvant treatment for colon cancer. N Engl J Med. 2004;350(23):2343-51. https://doi.org/10.1056/ NEJMoa032709.

8. Oliveira PJ. Mitochondrial biology and experimental therapeutics: Springer; 2018. https://doi.org/10.1007/978-3-319-73344-9.

9. Fereidoonnezhad M, Faghih Z, Mojaddami A, Sakhteman A, Rezaei Z. A comparative docking studies of dichloroacetate analogues on four isozymes of pyruvate dehydrogenase kinase in humans. Dent. 2016;1 (4):5.

10. Shoshan-Barmatz V, Krelin Y, Shteinfer-Kuzmine A, Arif T. Voltage-dependent anion channel 1 as an emerging drug target for novel anti-cancer therapeutics. Front Oncol. 2017;7:154. https://doi.org/10.3389/fonc.2017.00154.

11. Chen J-B, Chern T-R, Wei T-T, Chen C-C, Lin J-H, Fang J-M. Design and synthesis of dual-action inhibitors targeting histone deacetylases and 3hydroxy-3-methylglutaryl coenzyme a reductase for cancer treatment. J Med Chem. 2013;56(9):3645-55. https://doi.org/10.1021/jm400179b.

12. Chong D, Ma L, Liu F, Zhang Z, Zhao S, Huo Q, et al. Synergistic antitumor effect of 3-bromopyruvate and 5-fluorouracil against human colorectal 
cancer through cell cycle arrest and induction of apoptosis. Anti-Cancer Drugs. 2017;28(8):831-40. https://doi.org/10.1097/CAD.0000000000000517.

13. Tong J, Xie G, He J, Li J, Pan F, Liang H. Synergistic antitumor effect of dichloroacetate in combination with 5 -fluorouracil in colorectal cancer. Biomed Res Int. 2011;2011:7. Article ID 740564.

14. Ozkan A, Isgor SB, Sengul G, Isgor YG. Computer vision based automated cell counting pipeline: a case study for HL60 cancer cell on hemocytometer. 2018;2956-62.

15. Rai Y, Pathak R, Kumari N, Sah DK, Pandey S, Kalra N, et al. Mitochondrial biogenesis and metabolic hyperactivation limits the application of MTT assay in the estimation of radiation induced growth inhibition. Sci Rep. 2018;8(1):1-15.

16. Chou TC. Theoretical basis, experimental design, and computerized simulation of synergism and antagonism in drug combination studies. Pharmacol Rev. 2006;58(3):621-81. https://doi.org/10.1124/pr.58.3.10.

17. Yang Q, Zhou Y, Wang J, Fu W, Li X. Study on the mechanism of excessive apoptosis of nucleus pulposus cells induced by shRNA-Piezo1 under abnormal mechanical stretch stress. J Cell Biochem. 2019;120(3):3989-97. https://doi.org/10.1002/jcb.27683.

18. Szychowski KA, Wnuk A, Rzemieniec J, Kajta M, Leszczyńska T, Wójtowicz AK Triclosan-evoked neurotoxicity involves NMDAR subunits with the specific role of GluN2A in caspase-3-dependent apoptosis. Mol Neurobiol. 2019; 56(1):1-12. https://doi.org/10.1007/s12035-018-1083-z.

19. Jiang W, Wang R, Liu D, Zuo M, Zhao C, Zhang T, et al. Protective effects of kaempferitrin on advanced glycation end products induce mesangial cell apoptosis and oxidative stress. Int J Mol Sci. 2018;19(11):3334. https://doi. org/10.3390/ijms19113334.

20. Ma Y, Wang Q, Zhu Q, Liu M, Chen D, Han Z, et al. Dual fluorescence nanoconjugates for ratiometric detection of reactive oxygen species in inflammatory cells. J Biophotonics. 2018;11(2):e201700015. https://doi.org/1 0.1002/jbio.201700015.

21. Bernard S, Agustriawan D. Identification of microRNA Targeting Cancer Gene of Colorectal Carcinoma in Caucasian Population. In: 2019 International Conference on Information and Communications Technology (ICOIACT): IEEE; 2019. p. 423-7.

22. Huang C-Y, Ju D-T, Chang C-F, Reddy PM, Velmurugan BK. A review on the effects of current chemotherapy drugs and natural agents in treating nonsmall cell lung cancer. Biomedicine. 2017;7(4):23.

23. Jeffe DB, Pérez M, Cole EF, Liu Y, Schootman M. The effects of surgery type and chemotherapy on early-stage breast cancer patients' quality of life over 2-year follow-up. Ann Surg Oncol. 2016;23(3):735-43. https://doi.org/10.124 5/s10434-015-4926-0.

24. Lee JJ, Beumer JH, Chu E. Therapeutic drug monitoring of 5-fluorouracil. Cancer Chemother Pharmacol. 2016;78(3):447-64. https://doi.org/10.1007/ s00280-016-3054-2.

25. Battogtokh G, Cho Y-Y, Lee JY, Lee HS, Kang HC. Mitochondrial-targeting anticancer agent conjugates and Nanocarrier Systems for Cancer Treatment. Front Pharmacol [internet]. 2018;9:922 Available from: https://www.ncbi.nlm. nih.gov/pubmed/30174604.

26. Ke X, Shen L. Molecular targeted therapy of cancer: the progress and future prospect. Front Lab Med. 2017;1 (2):69-75. https://doi.org/10.1016/j.flm.2017. 06.001 .

27. Wang T-A, Zhang X-D, Guo X-Y, Xian S-L, Lu Y-F. 3-Bromopyruvate and sodium citrate target glycolysis, suppress survivin, and induce mitochondrial-mediated apoptosis in gastric cancer cells and inhibit gastric orthotopic transplantation tumor growth. Oncol Rep. 2016;35(3):1287-96. https://doi.org/10.3892/or.2015.4511.

28. Ihrlund LS, Hernlund E, Khan O, Shoshan MC. 3-Bromopyruvate as inhibitor of tumour cell energy metabolism and chemopotentiator of platinum drugs. Mol Oncol. 2008;2(1):94-101. https:/doi.org/10.1016/j.molonc.2008.01.003.

29. Chen Y, Wei L, Zhang X, Liu X, Chen Y, Zhang S, et al. 3-Bromopyruvate sensitizes human breast cancer cells to TRAI L-induced apoptosis via the phosphorylated AMPK-mediated upregulation of DR5. 2018;40:2435-44.

30. Ayyanathan K, Kesaraju S, Dawson-Scully K, Weissbach H. Combination of sulindac and dichloroacetate kills cancer cells via oxidative damage. PLoS One [internet]. 2012;7(7):e39949 Available from: https://www.ncbi.nlm.nih. gov/pubmed/22866174.

31. Florio R, De Lellis L, Veschi S, Verginelli F, di Giacomo V, Gallorini M, et al. Effects of dichloroacetate as single agent or in combination with GW6471 and metformin in paraganglioma cells. Sci Rep. 2018:8(1):1-14.
32. Wong RSY. Apoptosis in cancer: from pathogenesis to treatment. J Exp Clin Cancer Res. 2011:30(1):87. https://doi.org/10.1186/1756-9966-30-87.

33. Nakajima Y, Kuranaga E. Caspase-dependent non-apoptotic processes in development. Cell Death Differ. 2017;24(8):1422-30. https://doi.org/10.1038/ cdd.2017.36.

34. Campbell KI, Tait SWG. Targeting BCL-2 regulated apoptosis in cancer. Open Biol [internet]. 2018;8(5):180002 Available from: https://www.ncbi.nlm. nih.gov/pubmed/29769323.

35. Pan Y, Ye C, Tian $\mathrm{Q}$, Yan S, Zeng X, Xiao C, et al. miR-145 suppresses the proliferation, invasion and migration of NSCLC cells by regulating the BAX/ BCL-2 ratio and the caspase-3 cascade. Oncol Lett. 2018;15(4):4337-43. https://doi.org/10.3892/ol.2018.7863.

\section{Publisher's Note}

Springer Nature remains neutral with regard to jurisdictional claims in published maps and institutional affiliations.
Ready to submit your research? Choose BMC and benefit from:

- fast, convenient online submission

- thorough peer review by experienced researchers in your field

- rapid publication on acceptance

- support for research data, including large and complex data types

- gold Open Access which fosters wider collaboration and increased citations

- maximum visibility for your research: over $100 \mathrm{M}$ website views per year

At BMC, research is always in progress.

Learn more biomedcentral.com/submissions 